\title{
The effect of principal supervision competence and teacher motivation on teacher performance in primary schools
}

\author{
Nurhasyim Nurhasyim ${ }^{1}$, Yasir Arafat ${ }^{2}$, Dessy Wardiah ${ }^{2}$ \\ ${ }^{1}$ Sekolah Dasar Negeri Muara Telang, Indonesia \\ ${ }^{2}$ Universitas PGRI Palembang, Indonesia
}

\section{Article Info}

\section{Article history:}

Received Jul11 ${ }^{\text {th }}, 2021$

Revised Aug 17 $7^{\text {th }}, 2021$

Accepted Aug 30, 2021

\section{Keyword:}

Supervision competence

Teacher's motivation

Teacher's performance

\begin{abstract}
This study aims to m engetahui and describe the effect of the competence of supervising principals on teacher performance in SD Negeri Muara Telang, me Knowing and describe the influence of teacher motivation on the performance of teachers in public primary schools Muara Telang, and Knowing and describing the effect of the competence of supervising principals and teacher motivation together on teacher performance in SD Negeri Muara Telang District. This research uses quantitative methods . The study population was all teachers at SD Negeri Muara Telang and the sample was obtained as many as 86 respondents . Data collection techniques using questionnaires, observation, and documentation. Data were analyzed by using linear regression formula is simple and multiple linear regression with SPSS.From the results of this study concluded that k Competency Supervision Principal affect the performance Elementary School Teachers in Muara Telang. Teacher motivation has an effect on teacher performance in primary schools in Muara Telang district . Principal Supervision competence and teacher motivation jointly influence teacher performance in SD Negeri Muara Telang District.
\end{abstract}

C 2021 The Authors. Published by IICET.

This is an open access article under the CC BY-NC-SA license (https://creativecommons.org/licenses/by-nc-sa/4.0

\section{Corresponding Author:}

Nurhasyim, N.,

Sekolah Dasar Negeri Muara Telang, Indonesia

Email: nuristinah376@gmail.com

\section{Introduction}

Educationis a long-terminvestment in human resources that hasstrategic value for the continuity of human civilization in the world. Therefore, almost all countries place the education variable as something important and major in the context of nation and state development . Likewise, Indonesia places education as something important and foremost. (Herabudin, 2011: 58)

The teacher has a mission and a tough task, but it is noble to bring the nation's buds to the peak of their dreams. Therefore, it is appropriate for teachers to have various competencies,professionalism, and teacher performance related to their duties and responsibilities. With good teachercompetence and good performance, it will be a professional one, both academically and non-academically.(Herabudin, 2011: 71)

According to Herabudin (2011: 18-19), education is a branch of science in general. Worse, educational experts have begun to realize that although the principles in various fields have similarities, both in process and in their objectives, in the world of education there are specificities that cannot be equated with other 
worlds, only that educators and students are two human figures that cannot be separated from education World. Educators, a substantial definition of education, are people who have the knowledge and skills to know their students. This influence comes from adults (created people and parts of it) and is shown to immature people. In an Indonesian perspective, the meaning, function, and objectives of education are formulated in the national education system law number 20 of 2003 in articles 1 and 3 "education is a conscious and planned effort to show the learning atmosphere and learning process so that students can actively develop their potential. to have religious spiritual strength,self-control, personality, which is needed by oneself, society, nation and state ".National education functions to develop abilities and shape the character and civilization of the nation, aiming at developing the potential of students to become human beings who believe and fear the one and only God, have noble character, are healthy, knowledgeable, creative, independent,andbecome democratic citizensand to be responsible.

The notion of leadership , to explain what leadership means, then, will be put forward first from the point of view where a person views or understands the nature of leadership, and then, based on this understanding, it will be seen how he formulates or defines it. For this reason, this section will be divided into two parts, namely a description of the concept of leadership and the definition of leadership (Purwanto , 2017: 24-25)

According to an ancient view, those who are chosen as leaders are people who have all the advantages of other people, such as the strongest, bravest, smartest person, who eats the most salt, and so on (Purwanto, 2017: 62-64).

Responsibility is the main requirementinleadershipWithout a sense of responsibility,one cannot be a leader.In everydaylife,bear responsibility often misinterpreted human to say"charge"which simply means daring to "give an answer" or strike actions, even if it's wrong or not good.

Responsible is understanding which contains the norms of ethical, social, and scientific, which means that the acts be justified it is good, acceptable and approved others / society, and it contains the truth yan $\mathrm{g}$ is general (Purwanto , 2017: 73).

Supervision (supervision) in accordance with the development of society and perkemba ngan education in our country Indonesia since the days Desc ajahan B elanda until the time kem e rdekaan until now the obligations and responsibilities of general education leaders and principals in particular experiencing growth and change as well.

Educational supervision is needed by teachers to improve their ability to carry out the tasks of managing the learning process effectively and efficiently [3].With the implementation of coaching and guidance provided by the principal,which later has an impact on the formation of teachers'professional attitudes. The professional attitude of teachers is very important in maintaining and improving the professionalism of teachers becauseitalways affects the behavior and daily activities of teachers.Professional behavior will be more manifested in teachers if the institution where they work pays more attention to coaching, shaping and developing professional attitudes (Pidarta, 2016 : 380).

Duty headmaster $\mathrm{h}$, in addition to set the course of the school, also must be able to work together and closely linked to the public. He is obliged to inspire the enthusiasm of the staff, teachers and school employees to work better; build and maintain kinship, cohesiveness and unity between teachers, employees and students; developing school curriculum, knowing school design and knowing how to run it; pay attention to and strive for the welfare of teachers and employees; and so on (Purwanto , 2017: 7 5-76).

The principalasaneducationadministrato isresponsible for the smooth implementation of education and teaching in his school.Therefore,to be able to carry out its objectives well, the head of the school should understand, master, and be able to carry out activities related to his functionas an educational administrator(Purwanto , 2017: 106) .

The duties of the principal towards teachers and school employees see this definition, so the principal's duty as a supervisor means that he should be good at researching, dancing, and determining which conditions are needed for the progress of his school to the maximum extent possible (Purwa nto , 2017: 115).

The principal is indeed obliged to motivate teachers and staff so that they can become employees who have self-respect and can actualize themselves, which is important in improving their performance(Permadi and Arifin, 2010: 85). Of course the other cells are impulses that come from within, this urge can also arise due to external stimuli. Efforts to reward teachers who are good and who have high achievement can also be made by the principal to show support. Good leadership of school principals can make members trust , loyal, and motivated to carry out organizational tasks optimally (Rusdiana, 2015: 63). 
Not only has the ability to provide motivation, but the principal must also be able to provide disciplinary guidance to his employees. The relationship between morale and employee discipline is very closely related. If they have high morale, then they will generally have discipline. Meanwhile, if they feel that every job is a burden, then they tend to carry out less productive activities. The attitude of discipline is not simply recording the past, but also determine the direction, what should be observed and avoided, so as to have the driving force or motiv ation (Permadi and Arifin, 2010: 110).

Performance is defined as anachievement, showing an activity or action and carrying out the tasks that have been assigned. Definition of performance often diiden tik k 's with a achievementwork. Because there are similarities between the performance of the job performance are: A person's work withinacertainperiod is a work achievement, whencomparedtotargets/targets,mutually agreed standardsor other possibilities in acertainplan (in Supardi 2014: 45).

This is supported by the findings of Hamzah et al. (2013) in Kuala Lumpur, Malaysia and He Fei, China mentioned that supervision practices have a positive and medium relationship to teacher satisfaction in Kuala Lumpur, while there was positive and strong relationship between them in He Fei . Then Saani (2013) in Ghana, West Africa also mentions that teacher supervision relates positively to teacher work performance. The appropriatestrategies of supervision in schools will increase teacher work performance.Then the research results of Sudarjat et al. (2015) in Bogor stated there is a very significant positive effect of regular supervision on the performance of the teachers, and There is a very significant positive effect of work motivation on the performance of teachers. When tested jointly, there is a very significant positive effect of the regular supervision and motivation to teacher performance.

Furthermore, the findings of Idris (2016) in East OKU, Palembang revealed that an education institution who has more strict supervision will have higher teachers 'professional competence and teachers who have higher work ethic will improve teachers' professional competence. Another finding obtained by Oyewole and Alonge (2013) in Ekiti State, Nigeria concluded that there was a significant relationship between instructional supervisory role performance of principals and the motivation of their teachers. A significant positive relationship was found between experience of principals in performing their instructional supervisory roles and the motivation of their teachers. Therefore, this study recommends that principals should pay more attention to their instructional supervisory role performance as it has a significant influence on the motivation of their staff. Shahzadi et al (2014) also concluded that a significant and positive relationship exists between employee motivation and employee performance.

According to the research results of Awan et al (2011) in Pakistan thatachievement motivation and self concept are significantly related to academic achievement.Then the findings ofNurkhasanah et al. (2012) mentions first, there is a positive and significant relationship between work motivation and teacher performance, the contribution of work motivation to teacher performance is $24.27 \%$. Second, there is a positive relationship between principal supervision and teacher performance, the contribution of principal supervision to teacher performance is $34.1 \%$. Third, there is a positive and significant relationship between principal supervision and work motivation together with teacher performance, the contribution of principal supervision and work motivation together on teacher performance is $40.7 \%$.

In dealing with this problem, there is a need to improve performance as an effort to improve the quality and quality of education in SD Negeri Muara Telang District, Banyuasin Regency. In fact, in the field, based on the results of interviews with the principal, that teacher performanceproblems need serious attention and handling involving all elements andstakeholders in education in general, more specifically in SD Negeri Muara Telang District, Banyuasin Regency.

The function of supervising supervision in education is not just a control tosee whether all activities have been carried out in accordance with the outlined plan or program, but more than that, supervision in education contains a broad meaning. Supervision activities include the determination of the conditions or terms of personnel and material needed for the creation of a situ ation learning the effectivenes, and to meet those conditions.

Supervisi implies a moredemoktatis.Initsimplementation,supervision is not only monitoring whether the teachers/employees carry out their duties properly as outlined, but also trying together with the teachers, how to improve the teaching and learning process. (Purwanto, 2017: 75-77)

The term motivation ( motivation) comes from the Latin word movere, which means " to move " (to move ). According to McDonald cited by Hamalik (2011: 158)" M otivation is an energy change within the person Characterized by affective arousal and anticipatory goal reaction ". "Motivation is a change in energy in a person's (personal) self which is marked by the emergence of feelings and reactions to 
achieve goals". According to Hilgard quotedby Leh Sanjaya (20 16: 29),namely "Motivation is a state that exists in a person that causes a person to carry outcertainactivities toachievecertaingoals ".So work motivation is an encouragementthat can cause someone to do activities or work to achieve goals.

According to Sardiman (2011: 73) "Motivation stems from the word" motive "which means the driving force that is within a person to carry out certain activities for the achievement of a goal".Mangkunegara(20 $12: 22)$ definesmotivationas a condition that makes motives move according to the needs of each individual. According to Uno $(2011: 1)$ defines motivation as a force, both from within and from outside that encourages a person to achieve certain predetermined goals. Meanwhile, Hasibuan(20 13 : 95)states that "Motivation is a gift.

Performance is an activity carried out to carry out, complete tasks and responsibilities in accordance with the expectations and goals that have been set, seen from the meaning of the word performance comes from the word performance.(Supardi, 2014: 45).

Teacher performance is the ability of a teacher to carry out learning tasks and be responsible for students being guided by improving student learning achievement. K. Therefore, teacher performance can be interpreted as a condition that shows a teacher's ability to carry out his duties and develop an act that is displayed by the teacher in or during learning activities (Supardi, 2014: 54).

Performance is more often referred to as achievement which is a"result "or "what comes out " ( outcomes) of a job and the contribution of human resources to the organization. According to the muktis in the muktis book (1995, quoted from Supardi, 2014:46). then the performance issue can be identified from several meanings.

Indicators of the performance of each individual, group or organ ization of criteria Pénil a his $\mathrm{n}$ particular criteria of performance of a person's "trainer" as follows: (1) the amount of training done throughout the year, (2) the total number of participants of the exercise program, (3) an increase in self trainees, (4) the value added of participants compared to those who did not participate in the program, and (5) the number of errors, absences, or inaction of trainees compared to those who did not attend the program. (Supardi, 2014: 48)

\section{Method}

The research on the effect of the competence of principal supervision and motivation on teacher performance in SD Negeri Muara Telang District to be conducted is a correlational quantitative research (cause-andeffect). This type of correlational research aims to determine the existence of a cause-and-effect relationship that affects each other and is related between research variables. This study consisted of threevariables in the form of three independent variables and one dependent variable.The independent variable in this studyisthe competenceof teachersupervision and motivation onteacherperformance.Thedependent variablein this study is the teacher's performance at the Muara Telang District Elementary School.

\section{Results and Discussions}

\section{The Effect of Principal's Supervision Competence on Teacher Performance}

SupervisingPrincipalcompetencegained from the research results in the form of distributing questionnaires to the respondentsas many as 86 people a teacher at Elementary School District of Muara telag District Banyuasin South Sumatra Province. The questionnaire consists of 20 items that have been previously validated.

The data collected was then analyzed to determine the effect of the supervisory competence of school principals on teacher performance in Public Elementary Schools in Banyuasin. In descriptive analysis, theaverage score of the principal's supervisorycompetence from the statement of item number one, namely the principal being the highest authority in the school, to the statement of item number twenty, namely the principal demands that the teacher make good plans and learning as quickly as possible., obtained an average result of 3.96 or $79.20 \%$ of respondents who stated that the supervisory competence of the principal was in the good category. So overallthe supervisorycompetencyindicatorsfor principals are in the good category, yes it isin the interval 3.40 - 4.19 (modificationSudjana, 2015: 32 ).For inferential analysis showed that partial competence supervision of the school principal have influence significantly tothe performance of teachers in which the results of the partial test ( $t$ test) significance $t$ worth 0.004 . 


\section{The Effect of Teacher Motivation on Teacher Performance}

Data Motivation Master obtained from the research results in the form of distributing questionnaires to the respondents as many as 86 people of teachers in public elementary school in the District ofMuara TelangdistrictBanyuasinSouth Sumatra Province. The questionnaire consists of 20 items that have been previously validated. The data collected was then analyzed to determine the effect ofteacher motivation on teacher performanceat the Muara Telang District Primary School. From the results of the respondents' questionnaire answers to both the item number one statement, to the item number twenty statement with an average value of 4.10 which is in the good category.

\section{The Effect of Principal Supervision Competencies and Teacher Motivation on Teacher} Performance

Principal'ssupervisorycompetenceand teachermotivation are independent variables and teacher performance is the dependent variable. The independent and dependent variables were collected using a questionnaire of 20 items.The data collected is then analyzed. In this third hypothesis, it is a simultaneous hypothesis, namely that there is an influence of the competence of school principal supervision and teacher motivation on teacher performance in the Muara Telang District Elementary Schools .

A nalisis data by using multiple linear regression formula or commonly called the F-test, $\mathrm{p}$ acyl analysis shows that $\mathrm{F}$ count is 17,786 . While the value of significant $\mathrm{F}$ is 0,000 , where the value is less than the value of accuracy $=0.1(\mathrm{Pv}<)$, meaning that there is a significant influence between thePrincipal's Supervision Competence (X 1 ), and Teacher Motivation(X 2 ) onPerformance( $Y$ ).

\section{Conclusions}

Based on the findings of the research that has been done, it can be concluded that there is a significant impact of the leadership style of the headmaster of themadrasah on the performance of teachers in MTs Negeri Sekayu District, there is a significant effect of work environment on teacher performance at MTs Negeri Sekayu District,And the leadership style of the head has an impact. Madrasah and work together on the success of teachers in the district of MTs Negeri Sekayu.

\section{References}

Ardiansyah, B. (2010). Berprestasi Tujuan Hidupku. Bali: Departemen Pendidikan Nasional Provinsi Bali Arikunto. (2010). Prosedur Penelitian suatu pendekatan Praktek. Jakarta: Rineka cipta.

Bafadal, Ibrahim. 2013. Manajemen Peningkatan Mutu Sekolah Dasar. Bumi Aksara. Jakarta

Fathurrohman\&Sutikno. (2011) Hubungan Yang Signifikan Antara Kecerdasan Emosi Dengan Loyalitas KerjaKaryawan. Jurnal universitas negeri makassar. Vol. VIII

Harapan, Edi. (2018). Pembiayaan Pendidikan. Palembang: NoerFikri Offset.

Iskandar. (2012). Psikologi Pendidikan. Ciputat: REFERENSI.

Mulyasa. (2013). Kurikulum berbasis Kompetensi:konep, karakter dan implikasi. Bandung: PT Remaja Rosdakarya. Ngalimun. (2018). Evaluasi dan Penilaian Pembelajaran. Yogyakarta: Penerbit Parama Ilmu.

Priansa, D. J. (2015). Manajemen Peserta Didik dan Model Pembelajaran. Bandung: ALFABETA.

Qomar, Mujamil. 2017. Manajemen Pendidikan Islam. Malang: Erlangga

Rifaldi\&Roesminingsih (2017). Pengaruh Supervisi Kepala Sekolah Dan Motivasi Kerja Guru Terhadap Kepuasan Kerja Guru Di Smk Adb Invest Se-Kota Surabaya. Jurnal Inspirasi Manajemen Pendidikan, Vol. 4 No. 4, April 2014, hlm. 122-133. Diakses 5 Februari 2019.

Sahertian\&Mateheru. 2013. Supervisi Dunia Pendidikan. Jakarta: RinekaCipta.

Sobri, Muhammad. 2017. Pengelolaan Pendidikan. Yogyakarta: Multi Pressindo.

Sugiyono. (2014). Statistika non parametrik untuk penelitian. Bandung: Alfabeta.

Syah, M. (2012). Psikologi Belajar. Jakarta: Rajawali Pers 